University of Nebraska - Lincoln

DigitalCommons@University of Nebraska - Lincoln

Agronomy \& Horticulture - Faculty Publications

Agronomy and Horticulture Department

2007

\title{
Grassland Composition Affects Season Shifts in Seed Preference by Pogonomyrmex barbatus (Hymenoptera: Myrmicinae) in the Edwards Plateau, Texas
}

\author{
Nancy Nicolai \\ University of Nebraska-Lincoln \\ Jerry L. Cook \\ Sam Houston State University, Huntsville, TX \\ Fred E. Smeins \\ Texas A\&M University, College Station, $T X$
}

Follow this and additional works at: https://digitalcommons.unl.edu/agronomyfacpub

Part of the Plant Sciences Commons

Nicolai, Nancy; Cook, Jerry L.; and Smeins, Fred E., "Grassland Composition Affects Season Shifts in Seed Preference by Pogonomyrmex barbatus (Hymenoptera: Myrmicinae) in the Edwards Plateau, Texas" (2007). Agronomy \& Horticulture -- Faculty Publications. 181.

https://digitalcommons.unl.edu/agronomyfacpub/181

This Article is brought to you for free and open access by the Agronomy and Horticulture Department at DigitalCommons@University of Nebraska - Lincoln. It has been accepted for inclusion in Agronomy \& Horticulture -Faculty Publications by an authorized administrator of DigitalCommons@University of Nebraska - Lincoln. 


\title{
Grassland Composition Affects Season Shifts in Seed Preference by Pogonomyrmex barbatus (Hymenoptera: Myrmicinae) in the Edwards Plateau, Texas
}

\author{
N. NICOLAI, ${ }^{1,2}$ J. L. COOK, ${ }^{3}$ AND F. E. SMEINS ${ }^{1}$
}

\begin{abstract}
Environ. Entomol. 36(2): 433-440 (2007)
ABSTRACT The effects of season and community composition as generated by livestock herbivory of differing intensity on seed species preference by Pogonomyrmex barbatus (F. Smith) were studied in a semiarid savanna on the Edward's Plateau, TX. Seasonal differences in nutrient requirements of the colony could lead to differential preferences for seeds harvested in spring and fall. Field cafeteria studies were conducted to test the hypothesis that late successional species, with their high nutrient content, would be chosen regardless of grazing intensity or season. Commercial seeds of known nutrient content were used to test the hypothesis that high protein levels would be chosen in spring and high carbohydrate levels in the fall. Naturally occurring seeds were differentially harvested and some were preferred regardless of relative availability. Total seed harvest in cafeteria experiments was higher in spring than in fall. Commercial seeds were harvested equally among treatments within a season; thus, nutrient selection was indistinguishable. Preference for native species was significantly different in both seasons but was influenced by a significant interaction with grazing treatments. Bouteloua curtipendula, a late successional mid-grass, was harvested significantly more in the spring than the fall and at higher rates in the heavily grazed treatment, rejecting the hypothesis that they would be chosen regardless of treatment or season. Seed preference for late successional grasses within heavily grazed communities may slow succession after grazing. During disturbance recovery, late successional species may be reduced by forager preference and rates of spring harvest.
\end{abstract}

KEY WORDS harvester ants, seed preference, granivory, foraging, nutritional attributes

Animals can facilitate or inhibit the trajectory of plant population dynamics after disturbances. Harvester ants can impact plant demographics by harvesting large numbers of seeds (Rissing 1988, Whitford and DiMarco 1995, Wagner 1997, MacMahon et al. 2000) and by selecting seed species differentially (Hobbs 1985, Crist and MacMahon 1992). The food value of a species depends on the insect's current nutritional requirements and the mix of nutrients present in available food sources (Wheeler 1994, Simpson and Raubenheimer 2001). This study assessed seed choice by the harvester ant Pogonomyrmex barbatus (F. Smith) during the spring and fall.

Pogonomyrmex barbatus is usually an important ant seed predator in arid communities through most of Mexico and north to Arizona, Kansas, and Colorado (Holldobler and Wilson 1990). Foragers gather large numbers of freshly fallen small seeds from herbaceous plant species, along with insects, feces, soil, and parts

${ }^{1}$ Department of Rangeland Ecology and Management, MS-2126, Texas A\&M University, College Station, TX 77843.

${ }^{2}$ Corresponding author: Jacob Blaustein Institutes for Desert Research, Ben-Gurion University of the Negev, 84990 Midreshet BenGurion, Israel (e-mail: acnic240@aol.com).

${ }^{3}$ Department of Biological Sciences, Box 2116, Sam Houston State University, Huntsville, TX 77341 of vegetation (Tabor 1998) along foraging trails that radiate from the nest to foraging areas. They forage nearly all year except during times of cold surface temperatures in winter. If the winter and spring conditions produces few seeds, colonies must feed off stored seed to produce new workers (MacKay and MacKay 1984, Holldobler and Wilson 1990, Gordon 1999, MacMahon et al. 2000).

Intensity of foraging is affected by nutritional requirements, climatic conditions, and seed abundance (Holldobler 1976, Rissing and Wheeler 1976, Gordon 1991, Lopez et al. 1993). Patterns of nutrient acquisition vary seasonally depending on the colony's nutritional requirements and reproductive status. Springharvested nourishment is dispersed to the growing brood and used by the queen for production of male and female alates. Specifically, protein is used by the queen for egg production and by larvae for growth, whereas workers use carbohydrates to sustain their activity (Wheeler 1994). New queens must obtain sufficient nutrition, before they disperse, to raise their first brood without feeding (Wheeler 1994). Fall seed storage for winter inactivity could also be an important factor in seed selection.

North American savannas and grasslands are highly dynamic ecosystems, largely controlled by a distur- 
bance regime consisting of herbivory, fire, and variable rainfall, which results in a mosaic of vegetation patches of differing sizes and ages (Smeins and Merrill 1988, Bazzaz 1996, Fuhlendorf and Smeins 1997, Fuhlendorf et al. 2001). Seed recruitment is an important process in the recovery of grasslands particularly from large-scale perturbations because seeds survive disturbances underground or are dispersed widely from surviving individuals.

Seed consumption becomes important to plant populations when it removes seed from the population or causes indirect, differential mortality among competing plants (Brown et al. 1979, Louda 1989, Hulme 1998). Recovery from seed could be altered by postdispersal seed predators before the disturbance, by altering the populations of seeds destined to survive in soil, and after the disturbance by harvesting freshly dispersed seeds. High granivory rates by ants are reported for California annual grassland (Marshall and Jain 1970), desert grassland (Pulliam and Brand 1975), and Australian cultivated grassland that results in annual ryegrass (Lolium rigidum) becoming extirpated, whereas other annual grass and dicot populations are reduced (McGowan 1969). Studies in the Sonoran and Chihuahuan Deserts showed that differences in seed selection by harvester ants change plant community structure by reducing the abundance of preferred species (Inouye et al. 1980, Samson et al. 1992) and by increasing plant diversity caused by harvesting seeds of the most abundant annual species (Brown et al. 1979, Rissing 1986). As part of the reproductive dynamics of grassland populations, seed mortality by predation might affect plant populations recovering from disturbances.

One factor responsible for the number and type of seeds selected is the availability of preferred seeds. Large herbivores can influence grassland composition by the frequency and intensity of herbivory. Heavy, continuous livestock grazing in a liveoak savanna parkland on the Edward's Plateau of Texas shifts plant community composition from grazing intolerant and generally larger seeded, late-successional mid-grasses to smaller seeded grazing resistant, early-successional short-grasses (Smeins and Merrill 1988, Fuhlendorf and Smeins 1997). Furthermore, species richness of forbs is reduced. Large seed size is correlated with higher amounts of nutrient storage tissues and to an establishment advantage in the lower light conditions of late successional vegetation communities (Grime and Jeffrey 1965, Jensen and Gutekunst 2003). In South Africa, Capon and O'Connor (1990) and Milton and Dean (1993) found that harvester ant seed preferences changed because of grazing, which altered seed availability. Such grazing-induced change in preferences could lead to deviations in plant species' establishment because seed selection can change plant community structure. Seed selection by harvester ants can be influenced by seed morphology (Davison 1982), size (Davidson 1978, Rissing 1981, Morehead and Feener 1998), seed density (Rissing and Wheeler 1976, Crist and MacMahon 1992, Kunin 1994), chemical properties (Gordon 1999), energy content (Kelrick et al. 1986, Fewell and Harrison 1991), and handling time (Pulliam and Brand 1975, Schoning et al. 2004).

Understanding harvester ant patterns of food selection under varying natural conditions improves the ability to determine potential consequences for plant populations and community dynamics. The aim of this study was to describe the spring and fall patterns of seed choice by $P$. barbatus after decades of intense herbivory in a liveoak savanna parkland on the Edward's Plateau, TX, as related to nutritional requirements of a colony and the differences between seed diversity and availability induced by grazing. We first determined if foragers collect seeds in relation to their availability. We then determined if they prefer late successional species regardless of availability, but relative to the season or large herbivore grazing intensity in their habitat. Last, we examined if they select seeds with high protein levels in the spring and high total carbohydrate levels in the fall.

\section{Materials and Methods}

Study Site and Species. Research was conducted at the Texas A\&M University Agricultural Research Station, a semiarid savanna parkland, the western edge of the Edwards Plateau Land Resource Area, TX $\left(3118^{\prime} \mathrm{N}\right.$; $\left.10028^{\prime} \mathrm{W}\right)$. Mean annual precipitation is 574 $\mathrm{mm}$ but variability between years is great, with a range of $357 \mathrm{~mm}$ and SD of $51 \mathrm{~mm}$ (Station Records). Vegetation at the station is a liveoak parkland, characterized by groves of Quercus virginiana, $Q$. pungens variety vaseyana, Juniperus ashei, and J. pinchotii, within a grassland of mid- and short-grass species and with a diversity of perennial dicots (Gould et al. 1960, Kuchler 1964, 1975, Smeins and Merrill 1988). The main periods of grass and dicot seed production occur in June and October. However, many dicots and one common grass, Stipa leucotricha, set seed in the spring.

The study was conducted in two 11-ha ungrazed exclosures and two 32-ha continuously, heavily grazed pastures. The two treatments are $\approx 2.5 \mathrm{~km}$ apart having similar soils and topography. The heavily grazed site dominated by grass species that tolerate intense herbivory including the short-grasses Hilaria belangeri and Boutelou trifida and three mid-grass Aristida species (Gould 1978, Fuhlendorf and Smeins 1998). Common dicots were Verbena canescens, Plantago rhodosperma, and other annual species that commonly occur in disturbed places. The ungrazed site was dominated by grazing-intolerant species including the mid-grasses Bouteloua curtipendula, Stipa leucotricha, and Tridens muticus, with a high diversity of perennial dicots such as Ratibida columnaris.

Pogonomyrmex barbatus Smith 1858 (subfamily Myrmicinae), is common at the station and its colonies numbered 5.1 colonies/ha in the ungrazed sites and 3.3 colonies/ha in the heavily grazed sites (Nicolai 2005). Voucher specimens are deposited in the Entomology Museum, Texas A\&M University. Nests are constructed underground with a bare soil disk on top (Rissing 1988, Whitford and DiMarco 1995, Wagner 
1997, MacMahon et al. 2000). This species primarily gather propagules, either fruit or seed, dispersed by grasses and dicots. Foraging occurs nearly all year except for the coldest months, from November to March. Colonies raise one generation of brood per year that become adults in April or May depending on adequate rainfall (Gordon 1999).

Seed Preference. Seed collection by workers returning to the nest was recorded and compared with the composition of vegetation in foraging areas to assess selection of seed species in both heavily grazed and ungrazed sites. Voucher specimens of seeds are deposited in the Tracy Herbarium, Texas A\&M University. To determine whether seeds were collected in similar proportions to seed availability, item retrieval was related to food availability at the end of the foraging trail. Foragers are recruited to patches of seeds along and at the end of foraging trails; most search for seeds in a foraging area at the end of the trail (Holldobler and Wilson 1990). Ten colonies were selected randomly from one pasture within each grazing treatment for a total of 20 colonies. Each of the 20 colonies was sampled once in August 2002 by intercepting 30 returning foragers per colony on a cleared trail $\approx 1.5 \mathrm{~m}$ from the nest entrance and retrieving their food. Individuals were caught using a dustbuster modified with a small bore collection tube. This routine was performed at each colony between 0800 and 1100 hours or 1800 and 2000 hours, which are the periods of highest observed daily activity over 4-18 August, for a total of 600 ants. Immediately after collections, the cleared trail was followed until the foraging area was found, and this was sampled in a $1-\mathrm{m}^{2}$ quadrant for percentage aerial cover of each species dispersing seeds. All seeds were stored and identified to species.

Seed preference was calculated by comparing the proportion of seeds per species collected by foragers on the trail to the proportion available in the sampled foraging area. Species occurrence was determined by including all seeding species with $>1 \%$ foliar cover in all of the $1-\mathrm{m}^{2}$ samples within either treatment that were found at more than one nest. At Sonora, seed availability (the density and diversity of seeds that can be harvested by foragers) is a challenge to measure accurately because dispersed seeds are highly variable at scales of $<1 \mathrm{~m}$ (Kinucan 1987). An estimate of seed availability was therefore calculated as follows: the median number of seeds on an individual plant was determined from 20 plants and multiplied by plant density in the $1-\mathrm{m}^{2}$ foraging area samples. Most seeds, including wind-dispersed species, fall near the parent (Hengeveld 1989, Bullock and Clarke 2000), and only species currently dispersing seed were sampled; therefore, this method was thought to be the best estimate of seed availability in the foraging area during the sampling period.

Selection among seed species and differences between the grazed and ungrazed treatments were compared using the electivity index, which estimates selection independent of availability in the foraging area (Chesson 1983). Using this index, selection for a seed species is interpreted as the collection of a seed spe- cies relative to the average collection of alternative seeds.

Seed preference and Electivity Index data in different species were compared using a one-way treatment in a completely randomized design. Data were non-normal and variances were unequal; therefore, a nonparametric analysis of variance (ANOVA) (Kruskal-Wallis) was used (Zar 1996). The grazing areas were not replicated, preventing a statistical comparison between treatments.

Grazing and Season Experiments. Four herbaceous species known to be harvested by P. barbatus were used to quantify seed preference directly under natural seed rain. Species were selected for their high densities during early or late recovery after long-term heavy grazing (Smeins and Merrill 1988, Fuhlendorf and Smeins 1997). P. rhodosperma is an annual dicot that typically disperses seed from March through April and is common during early to mid-recovery phases. Three grasses were chosen, Bouteloua curtipendula, a mid-grass species common in later phases of succession; Aristida species, a mid-grass occurring during mid-succession; and Hilaria belangeri, a short-grass, also occurring during mid-succession. P. rhodosperma and Aristida species were found in the highest proportions in the heavily grazed treatment, whereas B. curtipendula was found at highest densities in the ungrazed treatment. Weight of seeds offered included the grass spikelet including florets, glumes, and awns. Mean weights of propagules were as follows: H. belangeri, $0.17 \mathrm{mg}$; Aristida, species, $0.26 \mathrm{mg}$; B. curtipendula, $0.05 \mathrm{mg}$; P. rhodosperma, $0.06 \mathrm{mg}$.

Seeds were offered in 78 plastic petri dishes $168.9 \mathrm{~cm}^{2}$ in area $(12.7$ by $13.3 \mathrm{~cm})$ and $3.5 \mathrm{~cm}$ tall with ceiling spackle placed inside to provide a surface for the ants to run out of the dishes easily. Sixty seeds were placed in each dish at a density of $3,529 / \mathrm{m}$, which is 10 times the mean seed rain densities found for the Station (Kinucan 1987) and would represent a typical seed clump. Fifteen seeds of each species were mixed together when offered in a dish.

To determine whether selection was made based on nutrient content rather than morphological characteristics, three commercial non-native seeds were offered: lentil, brown rice, and sesame. Harvester ants generally prefer heavier over lighter seeds (Crist and MacMahon 1992). To reduce the weight factor, all commercial seeds were ground with a Thomas-Wiley Laboratory Mill (model no. 4) to similar weights: lentil, $0.39 \mathrm{~g}( \pm 0.07 \mathrm{CI} ; n=20)$; sesame $0.30 \mathrm{~g}( \pm 0.01 \mathrm{CI}$; $n=20)$; brown rice, $0.30 \mathrm{~g}( \pm 0.05 \mathrm{CI} ; n=20)$. Nutrient content was defined by the primary metabolic constituent of each species and was total carbohydrate, lipid, and protein. Each species had high levels of one nutrient compared with the other two (Table 1). Twenty seeds of each of the three commercial species were mixed together for a total of 60 seeds and presented to the ants in the same manner as the native species.

Three replicate dishes were placed along an active ant trail $\approx 1 \mathrm{~m}$ from the edge of the cleared area on top of the ant nest. Dishes were placed near nests because 
Table 1. Nutrient content $(\mathrm{g} / 100 \mathrm{~g})$ of commercial seeds offered to foraging workers

\begin{tabular}{lccc}
\hline \multicolumn{1}{c}{$\begin{array}{c}\text { Average } \\
\text { content }^{a}\end{array}$} & $\begin{array}{c}\text { Lentil } \\
\text { seed }\end{array}$ & $\begin{array}{c}\text { Sesame } \\
\text { seed }\end{array}$ & $\begin{array}{c}\text { Brown rice } \\
\text { seed }\end{array}$ \\
\hline Total carbohydrates & 57.10 & 23.50 & 76.20 \\
Lipids & 0.96 & 49.70 & 2.68 \\
Protein & 28.10 & 17.70 & 7.50 \\
\hline
\end{tabular}

${ }^{a}$ USDA 2002

preliminary studies showed that foragers took $2-3 \mathrm{~d}$ to discover dishes in foraging areas compared with within $2 \mathrm{~d}$ near nests. Dishes were in place before the colony became active in the morning. Seeds were offered throughout the foraging time or until five native or six commercial seeds of the most harvested species remained (to minimize effects of depletion).

Seeds were presented to foragers from 6 colonies in two heavily grazed and two ungrazed sites for a total of 24 colonies. Commercial seed experiments were conducted on 2 consecutive d during 11-14 April 2003, and native seeds were presented on 2 consecutive $d$ during 8-12 May 2003, when harvester ants were assumed to be raising their single brood generation for the year. Some colonies took $>1 \mathrm{~d}$ to find the trays, but once found, seeds were depleted in $1 \mathrm{~d}$. The month interval was because of rainfall events that precluded seed presentation. In the fall when harvester ants were assumed to be gathering seed for storage, commercial seeds were presented on 2 consecutive d during 22-24 October 2003 and native seeds on $2 \mathrm{~d}$ during 26-28 October 2003.

Because of the large number of uncollected seeds during the fall, the distribution of data were highly skewed even after transformations; therefore, nonparametric statistics were used for all analyses. Replicate dishes and replicate sites were not significantly different; thus, they were pooled within grazing treatment and within season. Separate tests were conducted to compare differences between grazing treatments, seed species, and seasons. A one-way treatment in a completely randomized design nonparametric ANOVA (Kruskal-Wallis) was used (Zar 1996). Contrasts were conducted to determine differences among species using the Q-statistic test (Zar 1996).

\section{Results}

Seed Preference. Colonies collected 25 species of seeds with $52 \%$ of these species shared between heavily grazed and ungrazed treatments. Thirteen species had $>1 \%$ relative foliar cover in foraging areas treatments and were also found at more than one nest (Table 2). These species were used for analyses to reduce the influence of rarity.

Seed preference, the relative number of seeds collected by foragers on the trail compared with seed availability in the foraging area, was significantly (Kruskal-Wallis $\mathrm{H}=47.6 ; P<0.001$ ) different among species. A preference value of one indicates species collection proportional to availability; therefore, as a conservative, split mean preference values within $50 \%$ of preference value $=1$ were considered to be selected in proportion to their availability, means $>50 \%$ were preferred, and means $<50 \%$ were not preferred. Of the species found in both grazing treatments, four species were preferred, six were not preferred, two were selected in proportion to their availability, and one changed preference between treatments (Fig. 1). There were no significant differences in preference between grazing treatments for those species that occurred in both, except for the introduced grass Eragrostis cilianensis, which changed from not preferred to being collected according to seed availability (Fig. 1). Results of the Electivity Indices were the same as preference values; thus, they provided no additional

Table 2. Relative no. of seed species harvested and mean seed availability found in $1-\mathrm{m}^{2}$ foraging areas in heavy and ungrazed treatments

\begin{tabular}{|c|c|c|c|c|}
\hline \multirow[b]{2}{*}{ Seed species ${ }^{a}$} & \multicolumn{2}{|c|}{ Ungrazed treatment } & \multicolumn{2}{|c|}{ Heavily grazed treatment } \\
\hline & $\begin{array}{l}\text { Ant collection } \\
\text { (relative no.) }\end{array}$ & $\begin{array}{c}\text { Foraging areas } \\
\text { (availability) }\end{array}$ & $\begin{array}{l}\text { Ant collection } \\
\text { (relative no.) }\end{array}$ & $\begin{array}{c}\text { Foraging areas } \\
\text { (availability) }\end{array}$ \\
\hline Aristida species & 0.003 & 600 & 0.030 & 3,216 \\
\hline Bouteloua curtipendula & 0.000 & 1,617 & - & - \\
\hline Bouteloua trifida & 0.033 & 0 & 0.093 & 180 \\
\hline Chaetopappa asteroides & 0.010 & 64 & 0.057 & 1,803 \\
\hline Croton monanthogynus & 0.003 & 250 & 0.020 & 0 \\
\hline Digitaria cognata & 0.033 & 393 & 0.010 & 0 \\
\hline Eragrostis cilianensis & 0.030 & 1,250 & 0.000 & 200 \\
\hline Erioneuron pilsosum & 0.057 & 0 & 0.010 & 152 \\
\hline Hedeoma drummondii & 0.000 & 963 & 0.000 & 208 \\
\hline Hilaria belangeri & 0.027 & 0 & 0.000 & 28 \\
\hline Panicum hallii & 0.270 & 5,310 & 0.063 & 3,000 \\
\hline Sida abutifolia & 0.187 & 95 & 0.270 & 207 \\
\hline Tridens muticus & 0.000 & 4,914 & - & - \\
\hline Total seeds (no.) & $0.812(244.000)$ & & $0.680(204.000)$ & \\
\hline
\end{tabular}

The species used in analyses had $>1 \%$ of total foliar cover and were found at more than one of the foraging areas in each treatment. Species with - were not found in that treatment. Remaining species and nonseed material are not presented.

${ }^{a}$ Plant species unused in the analysis were Boerhaavia lineari, Bothriochloa barbinodis, Daucus pusillus, Eriochloa sericea, Lepidium austrinum, Panicum obtusum, Plantago helleri, Ratibida columnifera, Schedonnardus paniculatus, Scutellaria drummondii, Stipa leucotricha, and Verbena canescens. 


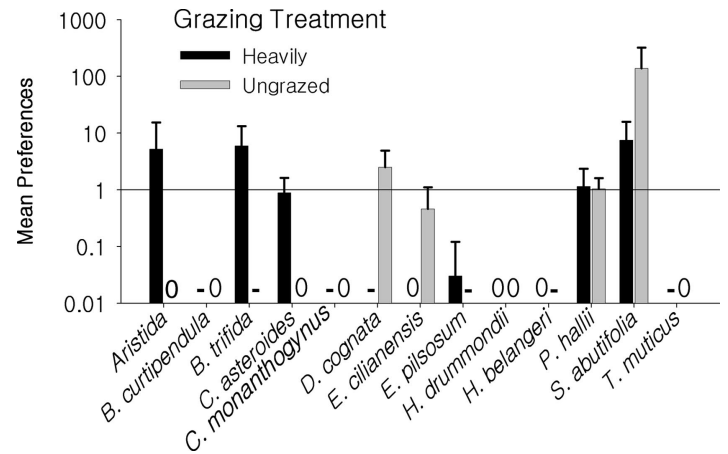

Fig. 1. Mean preference of species collected by P. barbatus colonies in heavily grazed and ungrazed treatments. A preference value of $1=$ species collected proportional to availability; a preference value of $0=$ species collected at a lower proportion than the availability; a preference value of $>1=$ species collected at a higher proportion than the availability; and a preference value of $-=$ species absent from foraging areas. Sample sizes were 2-12 nests. Error bars are SDs.

information and are not included (Nicolai 2005). The most available species in the foraging areas, Panicum hallii, Chaetopappa asteroides, Aristida species, Tridens muticus, and B. curtipendula (Table 2), varied in preference (Fig. 1). Generally, foragers did not choose seeds relative to their availability.

Grazing and Season Experiments. A significantly greater proportion of seeds were harvested from dishes in the spring compared with the fall for both total native (Kruskal-Wallis $\mathrm{H}=22.1$; $\mathrm{df}=1 ; P<$ 0.001 ) and total commercial seeds (Kruskal-Wallis $\mathrm{H}=32.6 ; \mathrm{df}=1 ; P<0.001)$ across both grazing treatments (Fig. 2). However, individual species ex-
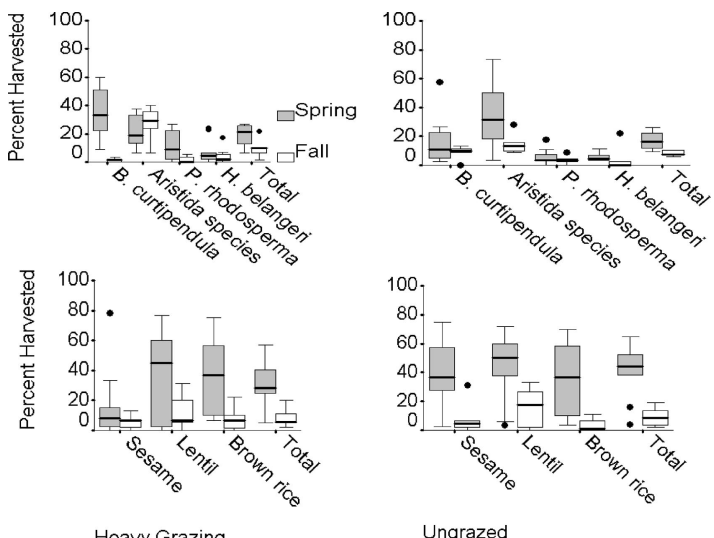

Heavy Grazing

Fig. 2. Median with an interquartile range that lies between 25 and $75 \%$ for ranked data of the percentage of seed species and total species harvested by P. barbatus from the total presented during the spring and fall seed selection in heavy grazed and ungrazed treatments. Boxes above the median are $25 \%$ below the ranked data and boxes below the median are $25 \%$ above. Bars represent $75 \%$ of the interquartile range, and symbols above bars are data points found at $>75 \%$. Spring, $N=208$ trays; fall, $N=120$ trays.
Table 3. Summary of Kruskal-Wallis multiple contrasts for $P$. barbatus seed selection during spring and fall 2003 among seed species

\begin{tabular}{lcclccc}
\hline \hline \multirow{2}{*}{ Species } & \multicolumn{2}{c}{ Native } & \multirow{2}{*}{ Species } & \multicolumn{2}{c}{ Commercial } \\
\cline { 2 - 3 } \cline { 5 - 6 } & $\mathrm{df}$ & $\mathrm{H}$ & & $\mathrm{df}$ & $\mathrm{H}$ \\
\hline Bouteloua curtipendula & 1 & $28.7^{b}$ & Sesame & 1 & $5.5^{a}$ \\
Aristida species & 1 & 1.0 & Lentil & 1 & $10.2^{b}$ \\
Hilaria belangeri & 1 & 3.3 & Brown rice & 1 & $20.3^{b}$ \\
Plantago rhodosperma & 1 & $5.6^{a}$ & & & \\
\hline
\end{tabular}

Grazing treatments were pooled: spring, $N=208$ trays; fall, $N=120$ trays.

${ }^{a} P<0.05 ;{ }^{b} P=0.001$.

hibited differing patterns between seasons. Bouteloua curtipendula and P. rhodosperma were harvested significantly more in the spring, whereas Aristida species and $H$. belangeri were not significantly different (Table 3). All commercial species were harvested significantly more in the spring compared with the fall (Table 3).

The Kruskal-Wallis statistic cannot test for interactions between factors, but inspection of the median percent of seeds harvested suggests possible interaction effects between grazing treatment and season for three of the species (Fig. 2). Bouteloua curtipendula was harvested more in the heavily grazed compared with the ungrazed treatment in the spring, but in the fall, very few seeds were harvested in either treatment (Fig. 2). In contrast, Aristida species were harvested $\approx 10 \%$ more in the ungrazed than in the heavily grazed treatment in the spring, but fall foragers decreased their harvest in the ungrazed treatment and increased it in the heavily grazed treatment. Commercial species also showed interaction effects, with sesame being selected much less in the spring in the heavily grazed treatment (Fig. 2).

Median seed removal between grazing treatments for both native (Kruskal-Wallis $\mathrm{H}=1.5 ; \mathrm{df}=1 ; P=$ 0.23 ) and commercial (Kruskal-Wallis $\mathrm{H}=1.0$; $\mathrm{df}=1$; $P=0.32$ ) seeds was not significantly different during spring experiments. When grazing treatment data were pooled, native seed preference was significantly different among species (Kruskal-Wallis $\mathrm{H}=47.6$; $\mathrm{df}=3 ; P<0.001 ;$ Fig. 3). Multiple comparison Q-tests (Zar 1996) found that the two mid-grasses, B. curtipendula and Aristida species, were harvested significantly more than $H$. belangeri $\left(Q_{0.05,4}=5.30\right.$ and $\mathrm{Q}_{0.05,4}=5.21$, respectively) and P. rhodosperma $\left(\mathrm{Q}_{0.05,4}=4.29\right.$ and $\mathrm{Q}_{0.05,4}=4.20$, respectively $)$. The late-succession species, B. curtipendula, was selected but so was the early-succession Aristida species; nevertheless, the remaining two early-succession species were rarely collected. Commercial seeds were selected equally among species (Kruskal-Wallis $\mathrm{H}=3.5$; $\mathrm{df}=2 ; P=0.17 ;$ Fig. 3 ), failing to elicit choice for seed species with varying amounts of protein, total carbohydrates, and lipids.

Fall experiments again were not significantly different between grazing treatments for both native (Kruskal-Wallis $\mathrm{H}=1.0$; $\mathrm{df}=1 ; P=0.33$ ) and commercial (Kruskal-Wallis $\mathrm{H}=0.7$; $\mathrm{df}=1 ; P=0.39$ ) 

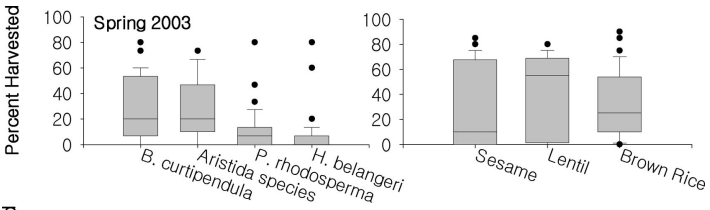

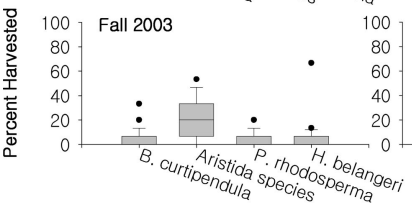

Native Seeds

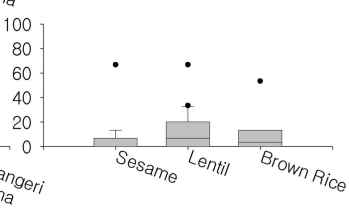

Commercial Seeds
Fig. 3. Median with an interquartile range that lies between 25 and $75 \%$ for ranked data of the percentage of seed species harvested by $P$. barbatus from the total presented during the spring and fall seed selection in pooled grazing treatments. Boxes above the median are $25 \%$ below the ranked data, and boxes below the median are $25 \%$ above. Bars represent $75 \%$ of the interquartile range, and symbols above bars are data points found at $>75 \%$.

seeds. Seed selection was significantly different among native species (Kruskal-Wallis $\mathrm{H}=35.0$; $\mathrm{df}=3 ; \mathrm{P}<$ 0.001; Fig. 3). Multiple comparison Q-tests showed that Aristida species were selected significantly more than any other species (B. curtipendula, $\mathrm{Q}_{0.05,4}=4.33$; $H$. belangeri, $\mathrm{Q}_{0.054}=4.33$; P. rhodosperma, $\mathrm{Q}_{0.054}=$ 4.28 ), and in contrast to spring, B. curtipendula was rarely collected and was not significantly different from $H$. belangeri and P. rhodosperma (Fig. 3). Again, commercial seeds were selected similarly among species (Kruskal-Wallis $\mathrm{H}=2.6 ; \mathrm{df}=2 ; P=0.28$; Fig. 3) .

\section{Discussion}

Pogonomyrmex barbatus foragers collected $69 \%$ of species used in the analysis. They collected differentially among most dicot and grass seeds, regardless of availability in natural conditions; consequently, the first hypothesis that foragers will collect species of seeds in direct relation to their availability was rejected. Species with the highest seed availability in foraging areas, P. hallii and T. muticus, had mean seed preferences of 1 and 0 , respectively, and those with lower seed availability, such as Aristida species and S. abutifolia, had mean preferences of 5 and 138, respectively; therefore, seed availability was unimportant in relation to seed preference. In contrast, previous studies found that Pogonomyrmex foragers did collect seeds relative to their availability (Pulliam and Brand 1975, Whitford 1978, Fewell and Harrison 1991, Crist and MacMahon 1992). Some studies have documented comparable patterns of seed selection when overall seed abundance is high (Davidson 1978, Whitford 1978, Hobbs 1985, Wilby and Shachak 2000). Rissing and Wheeler (1976) observed that, during low abundance, foragers gather species in relation to their availability. Crist and MacMahon (1992) affirmed this pattern among preferred seed species, but nonpreferred species were rarely chosen regardless of their abundance. During this study, sufficient rainfall and cooler July temperatures resulted in substantial seed production. This higher abundance of seed could have encouraged greater seed selection. High SDs in species preference (Fig. 1) indicate that there was internest variability that could be caused by (1) variation in searching ability of foragers, (2) temporal variability in plant dispersal of seed, (3) intraspecific competition for foraging areas (Gordon and Kulig 1996), and (4) the spatial patchiness of seeds (Kinucan 1987, Louda 1989, Wilby and Shachak 2000). Rare seeds may have much lower chance of being found, even if they are preferred (Kunin 1994).

Some species remain uncollected or rejected regardless of natural occurrence. Most cues determining seed choice in harvester ants are unknown. Leaf-cutter ants of the genus Acromyrmex attack many species of plants, and they strongly prefer some species over others (Roces 1994). Some ant species can discriminate among leaves on the basis of nutrients and odors (Holldobler and Wilson 1990, Roces 1994). However, for both leaf-cutter and harvester ants, the basis for the preference of some plant species over others remains unclear.

Pogonomyrmex barbatus foragers were selective under spring experimental conditions when they harvested 28.3\% B. curtipendula and 27.3\% Aristida species, which was significantly $>10.1 \%$ for $P$. rhodosperma or $6.9 \%$ for $\mathrm{H}$. belangeri. The hypothesis that B. curtipendula, a late-succession species, would be preferred over the other three, early-succession species, was rejected based on the equally high harvest of Aristida species in the spring and the significantly lower harvest of B. curtipendula in the fall when it was selected equally with the early-succession species $H$. belangeri and P. rhodosperma (Fig. 2). Two mechanisms could be responsible for this selection pattern. First, harvester ants can select among nutrients (Kay 2002); thus, foragers are capable of choosing seeds relative to their nutritional contents. Second, colonies may have experience with the shelf-life of seeds and may choose those that are long lived, although there are currently no data to support the idea that ants can make this discrimination. Shelf-life is important because colonies need stored seeds for their own use and for raising their brood during winter, a time when they are not foraging. Finally, P. rhodosperma may not have been harvested because it uses a dispersal mechanism called myxospermy that causes its seeds to adhere to soil with a mucilaginous layer when the seed is dampened. Myxospermy makes the seed unattractive to ant predators and reduces seed predation rates (Schoning et al. 2004)

Total seed harvest was significantly reduced in the fall relative to the spring. A reduced harvest of $B$. curtipendula seeds in the fall could be attributable to lack of a brood, because adults may be unable to process $B$. curtipendula for nutrients by themselves. In the fall, P. barbatus behavior is inconsistent with the results of previous studies that showed that, when seed abundance is high, there are correspondingly high foraging rates (Wilby and Shachak 2000). The experimental data of this study showed no corresponding increase in harvest rate with increased seed production in October, after fall rains. 
There were no differences among median percent harvest in seeds with known nutrient levels (Table 3); consequently, the third hypothesis, that foragers will select seeds with high protein levels in the spring and high total carbohydrate levels in the fall, was rejected. Similar results were reported for other Pogonomyrmex species (Kelrick et al. 1986, Fewell and Harrison 1991, Crist and MacMahon 1992). Fewell and Harrison (1991) found that Pogonomyrmex occidentalis preferred oats, probably because it was correlated with the highest caloric content. In this study, sesame had the highest caloric content, but because it was rejected during the spring, in the heavy grazing treatment in favor of the other two species, no apparent nutrient correlation can explain the result. The importance of carbohydrates versus proteins varies among ant species; however, it is unknown to what extent these nutrients are important to P. barbatus (Kay 2002). Nutrients in seeds are accessible to the colony but are constrained by features of the seed (such as myxospermy), foraging constraints (such as predation and competition), and environmental conditions. Separating confounding effects of seed features, secondary compounds, and nutritional contents remains difficult.

Grazing treatments differed in vegetation composition with heavily grazed treatment having a much higher proportion of early-successional species relative to the ungrazed treatment. Nevertheless, for species that were found in both treatments, colony preference patterns were not significant (Fig. 1). Preferences differed between grazing treatments only for the non-native grass, E. cilianensis, which was the only introduced grass seeding during the experiments (Fig. 1). Cover of this species was $4.8 \%$ in the ungrazed treatment and was selected proportionate to its availability compared with $1.0 \%$ cover in the heavily grazed with zero preference; therefore, colonies may have more experience with this species in ungrazed sites. No significant differences in median seed harvest were found between grazing treatments in the experiments; however, an interaction effect was observed between grazing treatment and season. Sesame was selected significantly less during spring in the heavily grazed treatment. B. curtipendula was selected significantly more in the heavily grazed than in the ungrazed treatment, but only during the spring (Fig. 2). Therefore, the hypothesis that the late-succession species, B. curtipendula will be preferred regardless of the grazing treatment was rejected, although its harvest may slow recovery in the heavily grazed treatment. These results contrast with studies that found differences in harvesting rates for species between grazed and ungrazed treatments (Capon and O'Connor 1990, Milton and Dean 1993). Although Milton and Dean (1993) found that selection varied with level of grazing, it was generally correlated with seed abundance.

Seed selection by $P$. barbatus foragers could modify plant community structure through the effects of seed harvest. Furthermore, recovery after intense grazing could be affected by seed selection if late-succession species are chosen. Sites recovering from heavy grazing are dependent on late-succession species whose seeds are typically short-lived in the seed bank (Kinucan 1987,
Louda 1989); therefore, as seeds disperse into grazed sites, plant establishment is vulnerable to seed predation by harvester ants. Although only a few late-succession species may be impacted by the preference of $P$. barbatus for their seed, these observations suggest that recovery after heavy grazing could be hindered by $P$. barbatus seed selection and rates of harvest in the spring.

\section{Acknowledgments}

This work was generously supported by the Texas A\&M Experiment Station at Sonora, TX. Help with identification of seed species was given by D. Kruse and S. Hatch at the S. M. Tracy Herbarium, Texas A\&M University, College Station, TX. The authors thank Z. Groner for careful review of the manuscript.

\section{References Cited}

Bazzaz, F. A. 1996. Plants in changing environments. Cambridge University Press, Cambridge, UK.

Brown, J. H., O. J. Reichman, and D. W. Davidson. 1979. Granivory in desert ecosystems. Annu. Rev. Ecol. Syst. 10: 201-227.

Bullock, J. M., and R. T. Clarke. 2000. Long distance seed dispersal by wind: measuring and modelling the tail of the curve. Oecologia (Berl.) 124: 506-521.

Capon, M. H., and T. G. O'Connor. 1990. The predation of perennial grass seeds in Transvaal savanna grasslands. S. Afr. J. Bot. 56: 11-15.

Chesson, J. 1983. The estimation and analysis of preference and its relationship to foraging models. Ecology 64: 12971304.

Crist, T. O., and J. A. MacMahon. 1992. Harvester ant foraging and shrub-steppe seeds: interactions of seed resources and seed use. Ecology 73: 1768-1779.

Davidson, D. W. 1978. Experimental tests of the optimal diet in two social insects. Behav. Ecol. Sociobiol. 4: 35-41.

Davison, E. 1982. Seed utilization by harvester ants, pp. 1-6. In C. Buckley (ed.), Ant-plant interactions in Australia. Dr. W. Junk, The Hague.

Fewell, J. H., and J. F. Harrison. 1991. Flexible seed selection by individual harvester ants, Pogonomyrmex occidentalis. Behav. Ecol. Sociobiol. 28: 377-384.

Fuhlendorf, S. D., and F. Smeins. 1997. Long-term vegetation dynamics mediated by herbivores, weather and fire in a Juniperus-Quercus savanna. J. Veg. Sci. 8: 819-828.

Fuhlendorf, S. D., and F. Smeins. 1998. The influence of soil depth on plant species response to grazing within a semi-arid savanna. Plant Ecol. 138: 89-96.

Fuhlendorf, S. D., D. D. Briske, and F. Smeins. 2001. Herbaceous vegetation change in variable rangeland environments: the relative contribution of grazing and climatic variability. Appl. Veg. Sci. 4: 177-188.

Gordon, D. M. 1991. Behavioral flexibility and the foraging ecology of seed eating ants. Am. Nat. 138: 379-411.

Gordon, D. M. 1999. Ants at work: how an insect society is organized, 1st ed. The Free Press, New York.

Gordon, D. M., and A. W. Kulig. 1996. Founding, foraging, and fighting: colony size and the spatial distribution of harvester ant nests. Ecology 77: 2393-2409.

Gould, F. W. 1978. Common Texas grasses, 1st ed. Texas A\&M University Press, College Station, TX.

Gould, F. W., G. O. Hoffman, and C. A. Rechenthin. 1960. Vegetational areas of Texas. Texas Agricultural Experiment Station, College Station, TX. 
Grime, J. P., and D. W. Jeffrey. 1965. Seedling establishment in vertical gradients of sunlight. J. Ecol. 53: 621-642.

Hengeveld, R. 1989. Dynamics of biological invasions. Chapman \& Hall, London, UK.

Hobbs, R. J. 1985. Harvester ant foraging and plant species distribution in annual grassland. Oecologia (Berl.) 67: 519-523.

Holldobler, B. 1976. Recruitment behavior, home range orientation and territoriality in harvester ants. Behav. Ecol. Sociobiol. 1: 3-44.

Holldobler, B., and E. O. Wilson. 1990. The ants. Harvard University Press, Cambridge, MA.

Hulme, P. E. 1998. Post-dispersal seed predation: consequences for plant demography and evolution. Perspect. Plant Ecol. Evolut. System. 1: 32-46.

Inouye, R. S., G. S. Byers, and J. H. Brown. 1980. Effects of predation and competition on survivorship, fecundity and community structure of desert annuals. Ecology 61: $1344-1351$

Jensen, K., and K. Gutekunst. 2003. Effects of litter on establishment of grassland plant species: the role of seed size and successional status. Basic Appl. Ecol. 4: 579-587.

Kay, A. 2002. Applying optimal foraging theory to assess nutrient availability ratios for ants. Ecology 83: 1935-1944.

Kelrick, M. I., J. A. MacMahon, R. R. Parmenter, and D. V. Sisson. 1986. Native seed preferences of shrubsteppe rodents, birds and ants: the relationships of seed attributes and seed use. Oecologia (Berl.) 68: 327-337.

Kinucan, R. J. 1987. Influence of soil seed bank, seed rain, inhibition competition and site disturbance on successional processes within three long-term grazing regimes on the Edwards Plateau, Texas. PhD dissertation, Texas A\&M University, College Station, TX.

Kuchler, A. W. 1964. The potential natural vegetation of the conterminous United States, 1st ed. American Geographical Society, New York.

Kuchler, A. W. 1975. The potential natural vegetation of the conterminous United States. American Geographical Society, New York.

Kunin, W. E. 1994. Density-dependent foraging in the harvester ant Messor ebeninus: two experiments. Oecologia (Berl.) 98: 328-335.

Lopez, F., F. J. Acosta, and J. M. Serrano. 1993. Responses of the trunk routes of a harvester ant to plant density. Oecologia (Berl.) 93: 109-113.

Louda, S. 1989. Predation in the dynamics of seed regeneration, pp. 26-51. In M. A. Leck, V. T. Parker, and R. L. Simpson (eds.), Ecology of soil seed banks. Academic, San Diego, CA.

MacKay, W. P., and E. E. MacKay. 1984. Why do ants store seeds in their nests? Sociobiology 9: 31-37.

MacMahon, J. A., J. F. Mull, and T. O. Crist. 2000. Harvester ants (Pogonomyrmex spp.): their community and ecosystem influences. Annu. Rev. Ecol. Syst. 31: 265-291.

Marshall, D. R., and S. K. Jain. 1970. Seed predation and dormancy in the population dynamics of Avena fatua and A. barbata. Ecology 51: 886-891.

McGowan, A. A. 1969. Effect of seed harvesting ants on the persistence of Wimmera ryegrass in pastures in northeastern Victoria. Aust. J. Exp. Agric. Anim. Husb. 9: 37-40.

Milton, S. J., and W.R.J. Dean. 1993. Selection of seeds by harvester ants (Messor capensis) in relation to condition of arid rangeland. J. Arid Environ. 24: 63-74.
Morehead, S., and D. Feener. 1998. Foraging behavior and morphology: seed selection in the harvester ant genus, Pogonomyrmex. Oecologia (Berl.) 114: 548-555.

Nicolai, N. 2005. Plant community dynamics governed by red harvester ant (Pogonomyrmex barbatus) activities and their role as drought refugia in a semi-arid savanna. $\mathrm{PhD}$ dissertation, Texas A\&M University, College Station, TX.

Pulliam, H. R., and M. R. Brand. 1975. The production and utilization of seeds in plains grassland of south-eastern Arizona. Ecology 56: 1158-1166.

Rissing, S. W. 1981. Foraging specializations of individual seed-harvester ants. Behav. Ecol. Sociobiol. 9: 149-152.

Rissing, S. W. 1986. Indirect effects of granivory by harvester ants: plant species composition and reproductive increase near ant nests. Oecologia (Berl.) 68: 231-234.

Rissing, S. W. 1988. Harvester ants and shrubs in the Mojave Desert. Ecology 69: 809-814.

Rissing, S. W., and J. Wheeler. 1976. Foraging responses of Veromesor pergandei to changes in seed production. Pan Pac. Entomol 52: 63-72.

Roces, F. 1994. Odour learning and decision-making during food collection in the leaf cutting ant, Acromyrmex lundi. Ins. Soc. 41: 235-239.

Samson, D. A., T. E. Phillippi, and D. W. Davidson. 1992. Granivory and competition as determinants of annual plant diversity in the Chihuahuan Desert. Oikos 65: 6180.

Schoning, C., X. Espadaler, I. Hensen, and F. Roces. 2004 Seed predators of the tussock-grass Stipa tenacissima L. by ants in southeastern Spain. J. Arid Environ. 56: 43-61.

Simpson, S., and D. Raubenheimer. 2001. The geometric analysis of nutrient-allelochemical interactions: a case study using locusts. Ecology 82: 422-439.

Smeins, F., and L. B. Merrill. 1988. Long-term change in a semi-arid grassland, pp. 144-164. In B. B. Amos and F. R. Gehlbach (eds.), Edwards Plateau vegetation. Baylor University Press, Waco, TX.

Tabor, S. W. 1998. The world of the harvester ants. Texas A\&M Press, College Station, TX.

U. S. Department of Agriculture [USDA]. 2002. Food composition. Nutrient data laboratory (www.nal.usda.gov/ fnic).

Wagner, E. 1997. Harvester ant nests, soil biota and soil chemistry. Oecologia (Berl.) 112: 232-236.

Wheeler, D. E. 1994. Nourishment in ants: patterns in individuals and societies, pp. 245-278. In J. H. Hunt and C. A. Nalepa (eds.), Nourishment and evolution in insect societies. Westview Press, Boulder, CO.

Whitford, W. G. 1978. Foraging in seed-harvester ants Pogonomyrmex spp. Ecology 59: 185-189.

Whitford, W. G., and R. DiMarco. 1995. Variability in soils and vegetation associated with harvester ant (Pogonomyrmex rugosus) nests on a Chihuahuan Desert watershed. Biol. Fertil. Soils. 20: 169-173.

Wilby, A., and M. Shachak. 2000. Harvester ant response to spatial and temporal heterogeneity in seed availability: pattern in the process of granivory. Oecologia (Berl.) 125: 495-503.

Zar, J. H. 1996. Biostatistical analysis, 3rd ed. Prentice Hall, Englewood Cliffs, NJ.

Received for publication 17 February 2006; accepted 15 October 2006 